\title{
The Implementation of Alternatives to Detention to Handle the Problems of Refugees in Indonesia
}

\author{
Wicipto Setiadi ${ }^{*}$, Mario Johanes Caesar Siagian** \\ DOI: https://doi.org/10.22304/pjih.v6n1.a7
}

Submitted: March 4, 2019 | Accepted: May 11, 2019

\begin{abstract}
In recent years, the numbers of refugees who transit in Indonesia are increasing. Since Indonesia is a state that upholds and respects human rights, the Indonesian government has an obligation to provide the best treatment and protection for refugees while they settle in the Indonesian territory. One of responsibilities of the state for these refugees is to implement programs that are alternatives to detention through the National Action Plan Beyond Detention 2014-2019. After the issuance of the Action Plan, the Indonesian government has collaborated with UNHCR and IOM to implement alternatives to detention in Indonesia. The alternatives are to provide care and the best protection for refugees living in the Indonesian territory. Refugees have to live in Indonesia temporarily because of various factors from the third countries. They have to stay for a while without a clear period until they are transferred to a third country of settlement. There are various problems in determining alternatives to detention in Indonesia. This paper aims to analyze and examine the policy of handling the problem of refugees in Indonesia since Indonesia has not ratified the Refugee Convention 1951.
\end{abstract}

Keywords: alternatives to detention, handling refugee problems, human rights.

\section{Penerapan Alternatif Terhadap Penahanan (Alternatives To Detention) dalam Menangani Permasalahan Pengungsi Luar Negeri di Indonesia}

\begin{abstract}
Abstrak
Dalam beberapa tahun terakhir, angka pengungsi yang singgah di Indonesia untuk sementara waktu mengalami peningkatan. Kebijakan pemerintah Indonesia yang menghormati dan menghargai HAM, membuat pemerintah berkewajiban memberikan perawatan dan perlindungan terbaik bagi para pengungsi yang tinggal di Indonesia. Salah satu program perlindungan yang digagas pemerintah adalah melakukan alternatif terhadap penahanan (alternative to detention) melalui Rencana Aksi Nasional Beyond Detention 2014-2019, bersama UNHCR dan IOM. Alternatif in bertujuan untuk
\end{abstract}

PADJADJARAN Journal of Law Volume 6 Number 1 Year 2019 [ISSN 2460-1543] [e-ISSN 2442-9325]

* Lecturer of Constitutional Law, at Faculty of Law, Universitas Pembangunan Nasional "Veteran" Jakarta, Jl. RS Fatmawati No. 1 Jakarta Selatan, S.H. (Universitas Gadjah Mada), M.H. (Universitas Padjadjaran), Dr. (Universitas Indonesia), wiciptos@gmail.com.

** Student of the Faculty of Law, Universitas Pembangunan Nasional "Veteran” Jakarta, JI. RS Fatmawati No. 1 Jakarta Selatan, S.H. (Universitas Pembangunan Nasional “Veteran” Jakarta), mario28siagian@gmail.com. 
menyediakan perawatan dan perlindungan terbaik terhadap pengungsi yang tinggal sementara tanpa harus melibatkan penahanan pengungsi di rumah detensi, sampai mereka dipindahkan ke negara ketiga. Terdapat beberapa masalah yang menghambat penentuan alternatif terhadap penahanan di Indonesia. Tulisan ini bertujuan untuk menganalisis dan memeriksa kebijakan Indonesia dalam mengatasi permasalahan pengungsi walaupun Indonesia tidak meratifikasi Konvensi Pengungsi 1951.

Kata kunci: alternatif terhadap penahanan, HAM, mengatasi masalah pengungsi.

\section{A. Introduction}

In recent years, the Indonesian government and the United Nations High Commissioner for Refugees (UNHCR) have faced considerable challenges with the increasing number of asylum seekers and refugees who are staying in the Indonesian territory. In the period of late 2015 to 2017, the number of refugees and asylum seekers has increased around 13,000 to 14,000 refugees. In 2016, the number of refugees seeking asylum or protection has experienced a significant increase, reaching 14,405, and only decreased by 4\% at the end of 2017 because only around 760 refugees who were successfully transferred to third countries. ${ }^{1}$

The phenomena prove that the refugees' opportunity to be placed in third countries is still very small even though the refugees have obtained their status as refugees. ${ }^{2}$ Various political and policy factors from third countries are one of the causes. ${ }^{3}$ One of the examples is Australia with Pacific Solution. ${ }^{4}$ Then, the United States of America with President Donald Trump's Travel Ban ${ }^{5}$ policy prohibits people from certain countries to enter their territory so that it brings implications for refugees. The refugees become unable to make resettlement for a better life in third countries. In short, they are forced to return to survival in uncertainty. ${ }^{6}$

The increase of refugees and asylum seekers is not proportional to the number of refugees who have been placed in third countries successfully. This resulted in

1 UNHCR, “Report: Indonesia”, http://reporting.unhcr.org/node/ 10335, accessed on April 2019.

2 Intan Pelangi, "Perlindungan Terhadap Para Pencari Suaka Berdasarkan Undang-Undang 39 tahun 1999", Padjadjaran Jurnal IImu Hukum, No. 4, 2017, pp. 156-158.

3 "the United States and Australia, the two main resettlement destinations for refugees in Indonesia, have put in place more stringent immigration policies, further decreasing their already long odds". See Joe Cochane, "Refugees in Indonesia Hoped for Brief Stay. Many May Be Stuck for Life". See Joe Cochrane, "Refugees in Indonesia Hoped for Brief Stay. Many May Be Stuck for Life", https://www.nytimes.com/2018/01/26/world/asia/indonesia-refugees-united-nations.html, accessed on April 2019.

$4 \quad$ “Australia's border security \& refugee policy so-called 'Pacific Solution', which entails the transfer of asylum seekers to camps in Nauru and Papua New Guinea, where they are detained pending determination of their refugee status and ultimate resettlement". See Opeskin, Brian, and Daniel Ghezelbash, "Australian Refugee Policy and its Impacts on Pacific Island Countries", Asia and Pacific Studies, Vol. 36, 2016, p. 1.

5 White House, "Executive Order 13769 of January 27, 2017: Protecting the Nation from Foreign Terrorist Entry into the United States," Federal Register 82, Vol. 20, 2017, https://www.govinfo.gov/content/pkg/FR-201702-01/pdf/2017-02281.pdf, accessed on April 2019.

6 Joe Cochane, loc.cit. 
difficulties for the UNHCR and the Indonesian government to accommodate asylum seekers and refugees who had only relied on Immigration Detention Centers (Rudenim-Rumah Detensi Imigrasi) and temporary shelters provided by the government with the assistance of relevant non-government organizations.

Refugees generally do not carry travel documents because it is impossible for them to be forced to leave their country by arranging visas and having passports or other documents. ${ }^{7}$ As a result, refugees seeking protection and asylum in Indonesia are treated as illegal immigrants according to immigration rules and regulations. ${ }^{8}$ Therefore, they may be treated like criminals in general, not as victims who should receive protection. One treatment for them is by detent in Rudenim. ${ }^{9}$

However, in the past few years, the use of Rudenim as a means and main effort to handle refugees in Indonesia began to get the attention of the government, related institutions, organizations, and the global community for various reasons. First, Rudenim has not been able to accommodate the overflowing of refugees. It has resulted in overcrowding due to the time of administration of refugee status determination and the acceptance of refugees that is not comparable to their expenditure to third countries and returning them to their country of origin. ${ }^{10}$ The overcrowd causes the refugees do not get a place in the Rudenim and the government bears very expensive costs to accommodate the large number of refugees and asylum. ${ }^{11}$ Second, another impact is human rights violations due to the treatment at the Rudenim and the desolate of refugees. The desolation can make them feel isolated and vulnerable to suicide due to long-term physical and psychological stress. ${ }^{12}$ According to a report by Human Rights Watch, cases happen due to the Indonesian government's policies and regulations that are misused in handling refugees so that they feel unprotected and abused..$^{13}$

Therefore, in 2014, the UNHCR introduced a program called Beyond Detention 2014-2019. Indonesia is one of the twelve countries that will adopt the program. ${ }^{14}$ The government is expected to stop detention for refugees and asylum seekers

\footnotetext{
Wagiman, Hukum Pengungsi Internasional, Jakarta: Sinar Grafika, 2012, p. 134.

Article 8(1) of the Law Number 8 of 2011 on Immigration [Undang-Undang Nomor 6 Tahun 2011 tentang Keimigrasian] (Immigration Law).

9 See Aritlce 83(1)(b) and (d) of Immigration Law.

10 UNHCR, "Beyond Detention 2014-2019:National Action Plan- Indonesia", http://www.unhcr.org/ 53aa929f6.pdf, accessed on September 2018.

12 Anbar Jayadi, "merasa terasing pengungsi di Indonesia rentan bunuh diri", https://theconversation.com/merasa-terasing-pengungsi-di-indonesia-rentan-bunuh-diri-95072, accessed on October 2018.

13 Human Rights Watch, "Barely Surviving: Detention, Abuse, and Neglect of Migrant Children in Indonesia", https://www.hrw.org/report/2013/06/barely-surviving/detention-abuse-and-neglect-migrant-childrenindonesia, accessed on September 2018.

14 Alice Edwards, "From Routine to Exceptional: Introduction to UNHCR's Global Strategy-Beyond Detention 2014-2019: Supporting Governments to End the Detention of Asylum Seekers," Refugee Survey Quarterly, Vol. 35, 2016, pp. 128-133.
}

11 Ibid. 
who seek protection in other countries. The program has three missions and objectives: ${ }^{15}$

1. end the Detention of Children;

2. ensure that alternatives to detention are available in law and implemented in practice;

3. ensure that conditions of detention, where detention in necessary and unavoidable, meet International Standards.

To help Indonesia implement this strategy, a National Action Plan was made together with relevant ministries, the UNHCR, The International Organization of Migration (IOM), and The National Commission on Human Rights (Indonesian: Komisi Nasional Hak Asasi Manusia, abbreviated to Komnas HAM). This strategy enables the government to open up and to realize that detention endanger detainees and cost quite a lot of money to accommodate the refugees in the Ruden$\mathrm{im}$. The government has also tried to find a cost-effective and more humane solution or way of treating refugees by implementing a program called alternatives to detention. ${ }^{16}$

After 2 years, in 2016, President Joko Widodo issued the Presidential Regulation Number 125 of 2016 on the Handling of Refugees. It is a quite big stepping stone to handle refugees in Indonesia. The Regulation provides new interpretations of refugees and the ways to handle refugees not as 'illegal immigrants' ${ }^{17}$ It also provides alternative to detention by working with UNHCR and IOM to protect them in the form of shelters and community houses ${ }^{18}$ with a periodic reporting system. ${ }^{19}$ The alternatives enables refugees not to be detained at the Rudenim.

However, the implementation of the alternative to detention as stipulated in the Presidential Regulation in practice still has not been able to provide protection to all refugees because the use of shelters is not able to accommodate all refugees living in the Indonesian territory. This is due to the limited numbers of accommodation and shelter that can be provided by UNHCR, IOM, and other institutions. They are only able to accommodate and to provide basic needs facilities to 8,688 refugees. There are still 5,145 refugees living in the Indonesian territory are forced to live independently. These individuals will likely be displaced and homeless due to lack of protection, especially in the context of legal perspective. ${ }^{20}$ In addition,

\footnotetext{
UNHCR, “Beyond Detention 2014-2019”, loc.cit.

16 See Antje Missbach, "Accommodating Asylum Seekers and Refugees in Indonesia: From Immigration Detention to Containment in Alternatives to Detention", Refuge: Canada's Journal on Refugees/Refuge: revue canadienne sur les réfugiés, 2017.

17 Article 1(1) of Regulation of the President of the Republic of Indonesia Number 125 of 2016 on the Handling of Foreign Refugees [Peraturan Presiden Nomor 125 Tahun 2016 tentang Penanganan Pengungsi dari Luar Negeri] (President Regulation 125-2016).

18 Article 24-30 of President Regulation 125-2016.

19 Article 33-39 of President Regulation 125-2016.

20 Data on refugees throughout Indonesia for the September 2018 period by the Directorate General of Immigration.
} 
the IOM issued a policy to stop providing accommodation for independent refugees who had just arrived and surrendered after March 15, 2018. It resulted in the 5,145 independent refugees are not able to obtain placements in community housing and temporary shelter. ${ }^{21}$

The Presidential Regulation Number 125 of 2016, which is supposed to handle refugees in Indonesia, cannot provide a solution to the problem of protection in terms of economic, social, and cultural rights of the refugees, especially for independent refugees who do not get assistance. ${ }^{22}$ Consequently, the Indonesian government, the UNHCR, and other related institutions have to seek alternative to detention so that the refugees can be protected. However, to provide such protection, the problem is, despite the Presidential Regulation, Indonesia has not yet ratified the International Convention ${ }^{23}$ \& Protocol $^{24}$ on Refugees to date. ${ }^{25}$ Therefore, Indonesia has no obligation to provide protection for refugees based on the state's sovereignty. The protection can risk the disruption or threat of the welfare and the security of the people and the state. ${ }^{26}$

On the other hand, Indonesia is not a legal state that only upholds sovereignty. It also bears responsibilities regarding human rights. The responsibilities have been contained in codified forms of laws as a commitment to provide protection of human rights to everyone, including refugees. ${ }^{27}$ Despite the fact that Indonesia has not ratified the 1951 \& 1967 Protocol on Refugees, the Indonesian Government remains committed to respect universal human rights. ${ }^{28}$ The concern is that if the Indonesian Government provides the protection for the refugees, it is possible that the interests of state sovereignty will be disrupted and threatened. On the contrary, if the Indonesian Government does not provide protection for refugees, the

21 The Instruction of the Director General of Immigration Number IMI-GR.02.03-1910 on the Amendment to the Policy for Handling Asylum Seekers and Refugees by IOM on April 30, 2018.

22 Yuliana Primawardani and Arief Rianto Kurniawan, "Penanganan Pengungsi dari Luar Negeri oleh Petugas Rumah Detensi Imigrasi di Provinsi Sulawesi Selatan”, Jurnal IImiah Kebijakan Hukum, Vol. 12, 2018, p. 182.

23 See Convention Relating to the Status of Refugees, 1951 (Refugee Convention 1951).

24 See Protocol Relating to the Status of Refugees, 1967 (Protocol 1967).

25 "Measures to accelerate accession to international instruments of refugee law by Indonesia have been attempted. During 1999-2002, the UNHCR Jakarta initiated two Round Table Discussions with the Indonesian House of Representatives on the possibility of Indonesia to accede to the 1951 convention and 1967 protocol. On 10 March 2003, a meeting was held between UNHCR Jakarta and the Chairperson of the Legislation Body to discuss the acceleration of accession by Indonesia to the convention but the result is deadlocked". See Wagiman, op.cit., p. 132.

26 "Economic factors are indeed the basis of the Indonesian government's consideration of refugee because the government has a series of responsibilities to ensure the survival of refugees in their country not only economic, but also cover social aspects including the civil and political rights of refugees as determined by the convention. The Indonesian government is not ready". See Fitria, "Perlindungan Hukum Bagi Pengungsi di Negara Ketiga: Praktik Indonesia”, Padjajaran Jurnal IImu Hukum, Vol. 2, 2015, pp. 113-114.

27 Article 28D of 1945 Constitution of the Republic of Indonesia [Undang-Undang Dasar Negara Republik Indonesia 1945] (1945 Constitution).

28 Yuliana Primawardadni and Arief Rianto Kurniawan, loc.cit. 
refugees will be threatened, abandoned, and become homeless, which are violations of human rights.

These put the Indonesian Government in a difficult situation. Consequently, there should be alternative option to detention in the form of a regulation without violating both the interests of sovereignty and human rights. Hence, this study provides a solution and opinion to provide the right understanding in formulating alternative to detention that is appropriate in dealing with the problems of refugees in Indonesia. The study employed analytical-normative-juridical approach.

\section{B. Regulation of Handling Refugees and Alternative to Detention in Indonesia}

The state of Indonesian does not have a fixed rule that specifically regulates refugees. This is because Indonesia is still not ready to ratify the 1951 Convention and the 1967 Protocol due to several considerations. However, by not ratifying the Convention, the Indonesian Government still continues to play a role to overcome the problem of refugees as one of the global issues. ${ }^{29}$ It is in line with the 1945 Constitution that Indonesia shall participate and involve in carrying out world order. ${ }^{30}$

Consequently, Indonesia accepts refugees in its territory to settle temporarily (transit) ${ }^{31}$ by giving a mandate ${ }^{32}$ to the $\mathrm{UNHCR}^{33}$ to be in charge of the refugees in the territory of Indonesia. The Government of Indonesia accepts refugees based on respect for human rights. The government applies the principles of legal protection for refugees in accordance with the 1951 Convention, namely nonrefoulement ${ }^{34}$, non-expulsion ${ }^{35}$, and non-discrimination ${ }^{36} .{ }^{37}$ These three principles are also stated in the 1945 Constitution as one of the principles of human rights that must be respected so that the Government has an obligation to respect these principles. In addition, the state also has to participate in carrying out world or-

29 United Nations, "Global Issues Overview", https://www.un.org/en/sections/issues-depth/global-issuesoverview/, accessed on April 2019.

30 See Paragraph 4 of the Preamble of 1945 Constitution.

31 Graeme Hugo (et.al), "Indonesia as a transit country in irregular migration to Australia" in Marie McAuliffe, Khalid Koser (eds.), A Long Way to Go: Irregular Migration Patterns, Processes, Drivers, and Decision-making, Canberra: ANU Press, 2017, p. 171.

32 "Since Indonesia has not ratified the 1951 Protocol and 1967 Conventions, Indonesia has no authority to provide assistance or action technically or administratively to refugees in its territory, such as determining refugee status, transferring refugees to third countries, etc." See Article 25 of Refugee Convention 1951.

33 According to the Statute of the High Commission of the United Nations, the UN High Commissioner for Refugees (UNHCR) which acts under the authority of the General Assembly, will hold the function of providing international protection. Under the auspices of the refugees, including the scope of this statute, and the search for permanent solutions for refugees assisting government concerned organizations, private agencies facilitate the voluntary repatriation of refugees intended to assimilate them in new national communities. See Article 33 of Refugee Convention 1951

Ibid.

See Article 3 of Refugee Convention 1951.

37 Yahya Sultoni, (et.al.), Alasan Indonesia Belum Meratifikasi Konvensi 1951 Tentang Pengungsi dan Perlindungan Hukum Bagi Pengungsi di Indonesia, Malang: Fakultas Hukum Universitas Brawijaya, 2014, p. 2. 
der. ${ }^{38}$ Therefore, Indonesia bears an obligation to handle refugees based on human rights commitment and the 1945 Constitution. ${ }^{39}$

The implementation of the handling of refugees in Indonesia must be carried out in accordance with national regulations and by taking into account international law, customs, and practices as stated in the Law on Foreign Relations. ${ }^{40}$ The absence of regulations specifically dealing with refugees, the government should handle refugees in accordance with immigration regulations that classify refugees as 'illegal immigrants' ${ }^{41}$ since they violate the provisions of the Law Number 6 of 2011 for entering Indonesian territory without Legitimate Travel Documents. ${ }^{42}$ The handling causes the refugees to be subjected to immigration measures as referred to in the Law of Immigration. They are required to be placed in the Rudenim with the status of criminal. ${ }^{43}$ According to international law, this treatment is not appropriate because refugees are basically victims, not criminals, who cannot be punished for illegally entering a country's territory. ${ }^{44}$ In terms of international human rights, this action violates fundamental rights such as freedom and personal security. In other words, refugees cannot be detained arbitrarily and they have freedom of movement to settle in an area. ${ }^{45}$

Misunderstandings or misconceptions about the status of refugees lead to the loss of access to these rights for refugees not only in Indonesia but also in other countries $^{46}$ so that they will be detained during their stay in the country. The act of detention can also have a negative effect that can damage human dignity of refugees, especially when they are held for a long period. It may affect their emotional and psychological conditions (anxiety, fear, and frustration). ${ }^{47}$ This was evidenced by the reports that illustrate the lack of protection, inappropriate treatment, and

38 Adlya Nova, “Perlindungan Hak Asasi Manusia Terhadap Pengungsi Dan Pencari Suaka Di Rumah Detensi Imigrasi Indonesia Berdasarkan Perspektif Hukum Internasional (Konvensi 1951 dan Protokol 1967)", undergraduate thesis, Faculty of Law Universitas Sumatera Utara, 2017, p. 64.

39 See Article $28(\mathrm{G})(2)$ of the 1945 Constitution.

40 See Article 26 of Law Number 37 of 1999 of Foreign Relations [Undang-Undang Nomor 37 Tahun 1999 tentang Hubungan Luar Negeri] (Foreign Relations Law).

41 Based on the Regulation of the Director General of Immigration Number IMI-1489.UM.08.05 of 2010 on the Handling of Illegal Immigrants, "illegal immigrants is foreigners who enter, or are in, Indonesian territory not in accordance with statutory provisions".

42 This is because the refugees in general are foreigners who enter the territory of Indonesia without valid travel documents as stipulated in Article 8 Paragraph 1 of Law Number 6 of 2011 on Immigration.

43 See Article 83(1) of Immigration Law.

44 See Article 31 of 1951 Convention.

45 See Article 9 of International Convention on Civil and Political Rights, 1969 (ICCPR).

46 "The 12 focus countries are: Canada, Hungary, Indonesia, Israel, Lithuania, Malaysia, Malta, Mexico, Thailand, the United Kingdom, the United States and Zambia." See UNHCR, “Progress Report Mid-16: Beyond Detention 2014-2019", https://www.refworld.org/docid/57dff0a912.html, 2016, p. 6.

47 UNHCR, "Beyond Detention 2014-2019: Global Strategy", https://www.unhcr.org/53aa929f6.pdf, 2014, p. 5. 
violence in which the UNHCR and the Indonesian Government were subjected to responsibility. ${ }^{48}$

Because of this concern, the UNHCR has introduced the global strategy entitled 'Beyond Detention 2014-2019' to help the government stop detention of refugees with a program called Alternative to Detention ${ }^{49}$. Indonesia is one of the countries to implement the policy. ${ }^{50}$ To help the Indonesian government adopt the strategy and program, the UNHCR Indonesia has created the National Action Plan with supports from relevant ministries and local partners such as non-governmental organizations, the IOM, and the Komnas HAM. ${ }^{51}$ In 2016, the National Action Plan is paid off. President Joko Widodo, who has the authority to establish policies on the issues of refugees ${ }^{52}$, issued the Presidential Regulation Number 125 of 2016 on the Handling of Refugees to address the problems of refugees in Indonesia. The Presidential Regulation makes the immigration rules invalid to be applied to refugees. ${ }^{53}$ Therefore, refugees are not treated as illegal immigrants according to their status mentioned in Presidential Regulation Number 125 of 2016. The regulation states that if a person who has foreign citizenship fled to Indonesian territory due to fear and does not want protection from her/his home country and/or has obtained refugee status from the UNHCR, the person is a refugee. ${ }^{54}$

According to Saputra ${ }^{55}$, the Presidential Regulation has canceled immigration rules and measures to refugees. Unless the refugee's status is rejected or revoked, the refugee can be subject to immigration measures in accordance with immigration regulations.

The absence of immigration measures for refugees makes the refugees will not be detained and placed at the Rudenim especially after the emergence of an im-

48 "Tells about an experience of refugees who provide a vivid picture of life in Immigration Detention Center such as beatings, bribery, bribery, lack of basic needs, and years of arbitrary detention". See Human Rights Watch, loc.cit.

49 "Alternative To Detention adalah suatu aturan, kebijakan atau praktik yang menyediakan pengungsi untuk tinggal di dalam masyarakat yang tunduk pada beberapa persyaratan atau batasan pada kebebasan mereka dalam bergerak berdasarkan standard Hak Asasi Manusia". See UNHCR, "Guidelines on the Applicable Criteria and Standards relating to the Detention of Asylum-Seekers and Alternatives to Detention", https://www.refworld.org/docid/503489533b8.html, 2012, p. 10.

50 Alice Edwards, loc.cit.

51 UNHCR, "Beyond Detention 2014-2019: National Action Plan- Indonesia", loc.cit.

52 See Article 27 of Law Number 39 of 1999 on Human Rights [Undang-Undang Nomor 39 Tahun 1999 tentang Hak Asasi Manusia] (Human Rights Law).

53 Interview with Jaya Saputra as the Head of the Division of Detention and Deportation of the Directorate General of Immigration on December 17, 2018.

54 Refugees are "foreigners who are in the Territory of the Republic of Indonesia that are fear of persecution based on race, ethnicity, religion, nationality, membership of certain social groups, and different political opinions. They do not want protection from their home countries and/or have obtained status as an asylum seeker or refugee status from the United Nations through the High Commissioner for Refugee Affairs in Indonesia". See Article 1(1) of the Presidential Regulation Number 125 of 2016,

55 Interview with Jaya Saputra as the Head of the Division of Detention and Deportation of the Directorate General of Immigration on December 17, 2018. 
migration circulation that refugees may not be placed again in the Rudenim. The refugees will be enforced based on the provisions of Articles 24 to 30 of the Presidential Regulation Number 125 of 2016. The Regulation provides enough protection for refugees in the form of treatment that is more humane and services with the mechanism of applying alternative to detention using accommodation community houses and shelter or shelter. ${ }^{56}$

However, the overwhelming number of refugees in 2018 across Indonesia, which reached 13,833 individuals, ${ }^{57}$ was not comparable to a shelter facility where the Government and the IOM could only provide facilities to 8,688 refugees. $^{58}$ The implications is that 5,145 refugees forced to live independently with uncertainty because they did not have sufficient access. This unpreparedness is certainly a problem for UNHCR and the Government of Indonesia in implementing alternative to detention policy efforts in accordance with the National Action Plan to provide protection for refugees as a whole not only for refugees who have obtained facilities but independent refugees.

\section{Problems of Alternative to Detention in Handling the Problems of Refugees in Indonesia}

1. Community House and Shelter or Temporarily Housings cannot Accommodate All Refugees Settling in Indonesian Territory

Community houses and shelters or temporarily housings are the spearheads of alternative to detention solution. They are considered unable to deal with the problems of refugees completely, especially after the Instruction of the Director General of Immigration, referred to as the 'March 15' policy, stating that after March 15, the IOM changed ${ }^{59}$ refugee-handling policy to stop giving assistance and accommodation to: ${ }^{60}$

1. refugees who come and are found in Indonesian waters but have destination other than Australia or New Zealand;

2. refugees who come independently and legally enter Indonesian territory then register themselves/report to UNHCR to obtain status of refugees; and

\footnotetext{
56 Shelter is provided and facilitated by the IOM and the regency/city government where the refugees get accommodations that can support their basic needs while settling in Indonesia, such as food, clothing, shelter, clean water and religious facilities.

57 Data on asylum seekers \& refugees throughout Indonesia for the September 2018 based on the UNHCR report by the Directorate General of Immigration.

58 Ibid.

59 The policy change was made for efficiency and budget savings as well as the reduction or tightening of assistance from the Australian government. In the end, IOM interprets it as a termination of assistance so that it had implications for the lack of facilities that could be provided for refugees. Based on the Instruction of the Director General of Immigration Number IMI-GR.02.03-1910 on Amendment to the Policy for Handling Asylum Seekers and Refugees by IOM on April 30, 2018.

60 Ibid.
} 
3. independent refugees who are found during routine surveillance operations of foreigners conducted by the immigration office or who surrender to the Immigration Detention House or to the Police Station.

This has a significant impact. The impact on the process of handling refugees in Indonesia is significant. If a refugee does not receive assistance from the IOM, she/he will be forced to live independently without accommodation from the IOM. In addition, the Immigration Detention House has a return policy that it is no longer serve as temporary shelter for refugees so that no refugee who is unable to live independently can surrender to be accommodated in an Immigration Detention House. ${ }^{61}$ After the issuance of the policy, at the end of 2018 , the refugees who did not receive accommodation were forced to live independently to fulfill their daily needs. In other words, the refugee must fulfill their basic needs, food, health, and housing. ${ }^{62}$

At first, independent refugees did not complain to paying for their own lives because when they arrived, they were still capable financially. They still had money to meet their needs when they arrived in Indonesia. ${ }^{63}$ However, due to the lack, even the opportunity to be processed ${ }^{64}$ into third countries was closed due to various policy factors, they were forced to stay for longer periods. It leads to the implication that they would not be able to fulfill their basic needs to live while settling in Indonesian territory. ${ }^{65}$

Opportunities for social assistance were felt to be impossible, especially after the IOM issued the policy of 'March 15'. Subsequently, a statement from a UNHCR representative explained their limited funding to help the refugees so they would prioritize those in need, around 300- 400 refugees, due to their limited capacity to assist. The UNHCR prioritized infants, children, or young people under the age of eighteen, old refugees, and refugees with special needs. ${ }^{66}$

Juridically, the Presidential Regulation Number 125 does not regulate the handling, treatment, and protection of independent refugees. At the time the regulation was issued, one of the solutions to handling refugees to be carried out was to

61 Instruction of the Ministry of Law and Human Rights of the Directorate General of Immigration Number IMIUM.01.01-2827 on the Return of the Function of the Immigration Detention House on July 30, 2018.

62 Interview with Jaya Saputra as the Head of the Division of Detention and Deportation of the Directorate General of Immigration on December 17, 2018.

63 Ibid.

64 "There were 19.9 million refugees of concern to UNHCR around the world at the end of 2017, but less than one per cent were resettled that year". See UNHCR, "Resettlement", https://www.unhcr.org/resettlement.html, accessed on April 2019.

65 Every year, UNHCR is only able to move and place refugees to the third country for 200 to 400 refugees each year or around $1 \%$ to $3 \%$ of the total refugees in the territory of Indonesia. Based on data from refugees in Indonesia as of June 30, 2018.

66 "Suicide, depression and poverty: Indonesia's Refugees bleak future now there's almost no change of being resettled". See Angela Jelita, "Suicide, depression and poverty: Indonesia's refugees' bleak future now there's almost no chance of being resettled", https://www.scmp.com/lifestyle/article/2137993/suicide-depressionand-poverty-indonesias-refugees-bleak-future-now-theres, accessed on December 2018. 
move them to settle in the community house and shelter or temporary housing. Generally, the UNHCR provides three solutions to handle the refugees in nonratifying countries: (1) repatriation, (2) integration in the host country, and (3) resettlement in third countries. ${ }^{67}$ However, according to current conditions, it is not possible for refugees in Indonesia to be returned to their home countries ${ }^{68}$ and placed in third countries ${ }^{69}$. One solution that can be given to these independent refugees is to seek an alternative to detention. Therefore, they can be empowered and get access to integration in the community. Hence, they can carry out activities and earn wages by working to fulfill their basic needs while settling in the Indonesian territory. ${ }^{70}$

Judging from a juridical perspective, according to Saputra ${ }^{71}$, there is actually no regulation that prohibits them from getting a job. Likewise, there are no provisions that allow them to work. Actually, based on national human rights instruments, the refugees have the right to work but providing such access gives impacts on the interests of state sovereignty.

\section{a. Conflict between the interest of state sovereignty and respect for human rights}

The Indonesian government cannot provide access of employment because Indonesia had not ratified the 1951 and 1967 Protocols, which substantially supported and provided protection for refugees to obtain such access so that refugees could financially meet their basic needs. Ratification is the form of consent to be bound in an international agreement so that a legal bond is established for the parties to carry out their rights and obligations in accordance with the applicable international agreement where the ratification must be ratified by the authorized body in respective country. ${ }^{72}$

In Indonesia, based on Article 11 of the 1945 Constitution of the Republic of Indonesia, the ratification of an international agreement must be carried out based on the approval of the authorized legislative body, namely the House of Representatives, by considering the impact of state sovereignty when binding to the agreement. Indonesia is a legal state that adheres to the notion or flow of legal

67 UNHCR, "The 10 -Point Plan (Solution for refugees: Chapter 7)", https://www.unhcr.org/50a4c17f9.pdf, accessed on April 2019, p. 16.

68 It is not possible to return the refugees to their home countries since there are still conflicts that can threaten the refugees. It will violate the principle of refoulment.

69 Policy factors in third countries make it difficult for resettlement of refugees in Indonesia

70 Rizki Akbar Hasan, "UNHCR Minta Pemerintah RI Upayakan Pemberdayaan Pengungsi di Indonesia”. https://www.liputan6.com/global/read/3490924/unhcr-minta-pemerintah-ri-upayakan-pemberdayaanpengungsi-di-indonesia, accessed on April 2019.

71 Interview with Jaya Saputra as the Head of the Division of Detention and Deportation of the Directorate General of Immigration on December 17, 2018.

72 Boer Mauna, Hukum Internasional: Pengertian, Peranan dan Fungsi dalam Era Dinamika Global, Bandung: PT Alumni, 2013, pp. 116-117. 
dualism. Legal dualism flows see that international law has a lower status than national law (primacy of national law), where the view also states that international law and national law are totally different and stand alone. ${ }^{73}$

Based on the understanding above, the rules that apply in the jurisdiction of Indonesia are the national law in the form of legislations. An international legal instrument can be implemented in Indonesian jurisdiction after it is ratified in a form of legislation through the process of ratification and approval by the legislature. Based on Article 2 of the Law Number 24 of 2004 on International Treaties ${ }^{74}$, an international legal instrument can be ratified and applied in Indonesian law and regulation if it fulfills some aspects. The aspects cover the interests of state sovereignty on public interests and the impacts and its implications for national or public sovereignty and interests when ratifying the agreement and the ability of the state to implement the rights and obligations of the international agreement after it has been ratified later.

There is a reason for Indonesia not to ratify the 1951 Convention and the 1967 Protocol yet. The convention is quite contrary to the interests and sovereignty of Indonesia. In other words, Indonesia has a limited capacity to fulfill obligations as referred to in the 1951 Convention and the 1967 Protocol on Refugees. Another reason is that Indonesia considers welfare aspects in the economic and social fields, considering that Indonesia is a developing country with high levels of unemployment and poverty as well as very low welfare levels. According to Sultoni ${ }^{75}$, there are several articles that are considered very difficult for Indonesia as follows:

1. Article 17 contains refugees' right to work. It is still very heavy given the narrow employment opportunities and a high unemployment rate.

2. Article 21 contains the right to get a house or a residence. This provision is very difficult considering there are still many people who need places to live due to the low level of welfare. in addition, there are still many underdeveloped regions that still need decent infrastructure from the central government so that providing shelter for refugees is very inappropriate and still far from the condition of Indonesia as a developing country.

These problems can be major concern and problem faced by the Indonesian government if it is going to provide a step or an option to get access to meet their needs as an alternative form of detention. In addition, the next concern is in terms of national security and defense. There are often immigrants who have expired visas or passports but they claim the status of asylum seekers or refugees for various reasons, ranging from persecution to status and access so they will not be de-

\footnotetext{
73 Jahawir Thontowi dan Pranoto Iskandar, Hukum Internasional Kontemporer, Bandung: PT Refika Aditama, 2016, p. 80.

74 See Article 2 of Law Number 24 of 2000 on International Treaties [Undang-Undang Nomor 24 Tahun 2000 Tentang Perjanjian Internasional].

75 Yahya Sultoni, (et al.), op.cit., pp. 8-9.
} 
ported and can stay indefinitely. ${ }^{76}$ If Indonesia provides favorable access for refugees, it is feared that the intensity of illegal immigrants trying to enter through these modes will increase due to their desire to obtain access illegally. Then the next problem is that if Indonesia provide this access, it is possible for many refugees to try to come to Indonesia because the availability of these accesses can be said to be quite profitable for them.

Based on these reasons and for the sake of state sovereignty, Indonesia needs to reconsider to provide such access as an alternative policy to detention. On the other hand, Indonesia is a country that upholds and respects human rights. The granting of access is in no way prohibited so that these refugees can fulfill their basic needs. Basically, even though Indonesia has not ratified the 1951 Convention and the 1967 Protocol, the protection of these accesses has been provided in national human rights instruments. We can say that human rights law instruments in Indonesia adequately support the implementation of the 1951 Convention and 1967 Protocol. Both provide protection criteria that can owned by a refugee:

1. The right to work and to get salary; ${ }^{77}$

2. The right to get a place to live; ${ }^{78}$

3. The right to education; ${ }^{79}$ and

4. The right to access health or social services. ${ }^{80}$

Then, to support the human rights principle above, we need to see again why these human rights principles need to be given and what are the basis of these human rights principles. Referring to the issues, independent refugees are refugees who live independently and are not financially assisted by any party in fulfilling their basic needs, namely food, drink, shelter, health. The basic needs must be fulfilled because the fulfillment of these basic needs means to live the refugees in the territory of Indonesia. Based on Article 28I of the 1945 Constitution of the Republic of Indonesia, the right to life is a human right that cannot be reduced and excluded from any interest or part of non-derogable rights. It is form of responsibility of the state to protect human rights.

Non-derogable rights are rights that cannot be reduced and excluded. They are based on Article 28I paragraph 1 of the 1945 Constitution and Article 4 of the Law Number 39 of 1999 on Human Rights. They cover the right to life, right not to be tortured, right to freedom personal, mind and conscience, religious rights, the right not to be enslaved, the right to be recognized as a person and equality before the law, the right not to be prosecuted on the basis of retroactive law. The nature

\footnotetext{
76 Interview with Jaya Saputra as the Head of the Division of Detention and Deportation of the Directorate General of Immigration on December 17, 2018.

See Article 38 of Human Rights Law.

See Article 40 of Human Rights Law.

See Article 12 of Human Rights Law.

See Article 41 of Human Rights Law.
} 
of human rights is universal, indivisible, interdependent, and interrelated as referred to in the Vienna Declaration. ${ }^{81}$ In the implementation, even if only nonderogable rights that cannot be excluded, it does not rule out the possibility that there are other rights that cannot be excluded so that the non-derogable rights can be exercised.

Therefore, the government must find a solution to protect the right of life of an independent refugee. An independent refugee must meet basic needs, namely meals, living, and getting health. To get these basic needs, they need funds independently since independent refugees do not get help from anywhere and to get these costs they need to work and get a salary because it is the only way to stay alive while settling in the Indonesian territory for a long period. Even though the right to work is not non-derogable rights, if the principle of human rights is not carried out or prohibited, which implies that the person cannot exercise his right as a human being where the right to life, it is a violation on the right to life. It is the state's obligations and responsibilities not to be excluded under any circumstances.

The implementation is basically the same with the condition when Indonesia does not expel and repatriate refugees (non-refoulment and non-expulsion) based on humanitarian grounds. The juridical basis of humanity is a form of respect for human rights. In fact, the principles of non-refoulment and non-expulsion are not required. Hence, based on Indonesian state sovereignty, the government has the right to expel or repatriate refugees. However, Indonesia accepted these refugees to enter the sovereign territory of Indonesia. This is done because Indonesia has an obligation to protect these refugees from persecution or torture. If Indonesia repatriates and expels these refugees, they can be tortured and persecuted. However, based on humanity and respect for human rights, Indonesia does not do so because the right not to be tortured and the right to live have the same position in Indonesia national legal system. The right not to be tortured is one of nonderogable rights that cannot be reduced and excluded under any circumstances. Therefore, Indonesia has been able to provide respect and protection of their fundamental rights, especially in the context of a refugee who can at least fulfill basic needs.

In terms of sovereignty, in a non-juridical sense, the dilemma of Indonesia in providing access is due to economic factors. Indonesia is a developing country that still needs to improve the welfare of its people. Therefore, the refugees can add an

81 "All human rights are universal, indivisible, and interdependent and interrelated. The international community must treat human rights globally in a fair and equal manner, on the same footing, and with the same emphasis. While the significance of national and regional particularities and various historical, cultural and religious backgrounds must be borne in mind, it is the duty of states, regardless of their political, economic and cultural systems, to promote and protect all human rights and fundamental freedoms". See Majda El Muhtaj, Dimensi-Dimensi HAM: Menggurai Hak Ekonomi, Sosial, dan Budaya, Jakarta: Rajawali Pers, 2013, p. 13. 
additional burden. Indonesia is not under obligation to grant the right to gain such access because Indonesia has not ratified the 1951 and 1967 Protocols. However, Indonesia acts in terms of respect for human rights. Access needs to be given as a form of respect and protection of its basic rights, namely the right to life and to the refugees' needs. That basic rights, especially the right to life owned by refugees can be fulfilled.

\section{b. There is no adequate legal protection}

The absence of the 1951 and 1967 Protocols in Indonesia's sovereignty resulted in the emergence of a legal vacuum in providing treatment and protection for refugees. The adoption of alternative to detention has reached a new stage to provide solutions for refugees especially protection for living refugees independently so that they can live without going against public order.

Legal protection is protection provided based on laws and regulations. ${ }^{82}$ Therefore, to understand legal protection, the subject of protection should be determined. In the context of refugees, the subject of protection is specifically for individual who is refugee. Provisions for handling refugees in Indonesia are regulated in the Presidential Regulation Number 125 of 2016 on the Handling of Foreign Refugees. The Regulation states that foreign refugees are ${ }^{83}$ "foreigners who are in the Territory of the Republic of Indonesia that are fear of persecution based on race, ethnicity, religion, nationality, membership of certain social groups, and different political opinions. They do not want protection from their home countries and/or have obtained status as an asylum seeker or refugee status from the United Nations through the High Commissioner for Refugee Affairs in Indonesia".

The presidential regulation, indeed, do not categorize refugee as illegal immigrant. Therefore, the handling of refugees is not based on the immigration regulations. However, the Presidential Regulation is only procedural. It does not discuss anything about the rights and authorities possessed by refugees. Saputra says that although the Presidential Regulation is not perfect since there are still many shortcomings the Regulation has been issued and has a binding nature. If it is not perfect, it does not mean it cannot be implemented. Furthermore, in the future the Regulation needs to be refined. ${ }^{84}$

Previously, the regulations on refugee are considered not clear yet when it is associated with the rights and obligations of refugees. After the issuance of the Presidential Regulation Number 125 of 2016, refugees are not treated as foreign-

82 Malahayati, (et.al.), "Konsep Perlindungan Hukum dan Hak Asasi Manusia Terhadap Penata Laksana Rumah Tangga Indonesia", Jurnal Nanggroe, Vol. 4, No. 1, 2015, p. 6.

83 See Article 1(1) of President Regulation 125-2016.

84 Interview with Jaya Saputra as the Head of the Division of Detention and Deportation of the Directorate General of Immigration on December 17, 2018. 
ers and illegal immigrants as referred to by the Law Number 6 of 2011 on Immigration.

If there is a legal vacuum in the context of refugees, the refugees are not bound by the Immigration Act because the Law of Immigration does not contain to the term 'refugee'. Therefore, the immigration provisions cannot be applied since the context is different in terms of terminology and handling. Thus, it can be concluded that, for now, there are no rules that prohibit refugees from obtaining certain rights and authorities and, vice versa, there are also no rules that allow or give refugees certain rights and authorities. Consequently, to date refugees can only rely on protection for the recognition of their basic rights or the principles of human rights as protected by national human rights law instruments. To implement these human rights principles, the government must make regulations on the implementation of human rights principles as stipulated in the 1945 Republic of Indonesia Constitution. It states that the implementation of human rights must be guaranteed, regulated, and set forth by Law. ${ }^{85}$ This policy is a refinement of refugee regulations, which is considered imperfect and needs further development. This is very urgent, especially considering that independent refugees still need special handling. The government shall determine appropriate policies through regulations that provide solutions for refugees so they aware of their rights, authority, and limitations in fulfilling their basic needs.

\section{Policies or Possible Solutions of the Indonesian Government to Ensure that Alternative to Detention can be Implemented in Indonesian Jurisdiction}

The alternative to detention policy contains the interests of refugees and is the authority of the State and the government to implement the policy based on Article 25, 26, and 27 of the Law Number 37 of 1999 on Foreign Relations. Therefore, the policy of handling refugees is classified as public policy, which must be stated in legislation so that it can be implemented legally in the jurisdiction of Indonesia. The implementation of human rights protection for refugees must refer to Article 281 paragraph 5 of the Republic of Indonesia Constitution of 1945. In the context of handling refugees, to ensure legal certainty the implementation of human rights to refugees must be regulated in legislation in accordance with established procedures based on the Law Number 37 of 1999 on Foreign Relations and the Law Number 39 of 1999 on Human Rights.

In practice, alternative to detention have actually been implemented in accordance with the provisions referred to in the Presidential Regulation Number 125 of 2016. However, there are still problems that the Regulation have not fully protected or covered, especially for independent refugees. They still face legal vacuum and uncertainty related to the way and the technical implementation as

85 See Article 28(I)(5) of 1945 Constitution. 
well as the rights to maintain their survival that they are vulnerable to human rights violations. This study is in the position that for now the handling of refugees shall refer to Article 3 of the Presidential Regulation Number 125 of $2016 .{ }^{86}$ It reads, "the handling of refugees takes into account international provisions that are generally accepted and in accordance with the provisions of the legislation." If we associate the provision of legal protection for refugees, especially related to human rights, then the basis and source of law that we can use as a form of legal protection for refugees is generally applicable international provisions that are in accordance with laws and regulations to provide protection of Human rights for refugees and legislation in Indonesia.

In the case of generally accepted international provisions that can provide protection for refugees, the 1951 Convention and the 1967 Protocol regulate human rights standards that must be implemented and given to refugees by host countries. Nevertheless, the problem is that Indonesia has not ratified the 1951 Convention and the 1967 Protocol. Therefore, Indonesia has no obligation to implement the provisions of the conventions and protocols. On the other hand, it turns out that the substance of human rights protection provided by the 1951 Convention and 1967 Protocol is basically the same as other international human rights instruments. Several substances have been regulated in international human rights instruments that have been ratified in national legislation.

In order for a principle to be categorized as general principles of international law, two things are needed. They are the acceptance and the recognition of the international community. Therefore, the human rights principles that have fulfilled both conditions have general law principles. ${ }^{87}$ This proves that Indonesia, as referred to by Starke, is a country that has an important achievement by the existence of a general recognition of human rights standards regardless of whether they are citizens concerned or not. ${ }^{88}$

To determine the policy of alternative to detention that is appropriate for independent refugees, it is necessary to examine the considerations in terms of sovereignty and protection of human rights. However, it can be concluded that, indirectly, Indonesia has received and recognized the rights granted to refugees in accordance with the 1951 and 1967 conventions through national human rights instruments. The instruments have protected the standard of refugees' basic rights as intended by the 1951 Convention and the 1967 Protocol.

In terms of current conditions, considerations that need to be considered in determining the right policy for handling independent refugees are as follows.

1. IOM closed the assistance of community housing and accommodation facilities for independent refugees since March 15, 2018. As an alternative to deten-

\footnotetext{
86 See Article 3 of President Regulation 125-2016.

87 Andrey Sujatmoko, Hukum HAM dan Hukum Humaniter, Jakarta: Rajawali Pers, 2016, p. 11.

88 J.G Starke, Pengantar Hukum Internasional, $10^{\text {th }}$ edition, Jakarta: Sinar Grafika, 2010, p. 481.
} 
tion, community housing facilities have not fully succeeded in providing protection for all refugees. It implicates the closed accommodation of 5145 refugees $^{89}$, namely independent refugees, to receive accommodation assistance to be able to fulfill their basic needs while settling in Indonesia.

2. There is only small opportunity to get assistance from UNHCR because of the lack of aid funds that can only be given to certain people who are prioritized and the quota only cover $300-400$ individuals. ${ }^{90}$

3. Since Indonesia has not ratified the 1951 Refugee Convention and the 1967 Protocol, there is fulfillment of rights that cannot be borne by the government because it involves the welfare of the people who are not yet prosperous and will become an additional burden if a refugee gets those rights.

4. Based on the aspects of defense and security, there are illegal practices are still vulnerable in the form of abuse of the use of refugee status for personal gain. Then for independent refugees, if indeed there is no legal certainty that implies their lives are threatened, it is possible that they will commit acts of crime in order to maintain their survival such as participating in drug business, terrorism, and other things that are contrary to order general solely to maintain their lives.

5. The obligation and responsibility of Indonesia provides protection and respect for the basic rights of refugees, particularly for the rights of refugees to live non-derogable rights related to the current conditions. At least 5,145 refugees must struggle without clear rules regarding the regulation of rights and authority. Independent refugees must be able to fulfill their basic needs financially while settling in Indonesia, which in practice many independent refugees have begun to give up their lives because they have been unable to fulfill their basic needs.

6. To fulfill their basic needs, namely food, drink, clothing, shelter, and access to health, a refugee needs money or accommodation to cover these basic needs so that they can run their lives to survive while settling in Indonesian territory before being placed in third country.

From these considerations, the only way or option to overcome the problems of independent refugees in Indonesia is to empower them to get wages so that they can fulfill their needs independently during their temporarily settle in Indonesia. Accommodation assistance is possible but the opportunities are very small and it is almost impossible to remember the above considerations so that refugees are expected to be able to live independently by not relying on meeting their needs from the Indonesian government's assistance.

\footnotetext{
89 Refugees who live independently in the territory of Indonesia after the policy of "March 15" based on the data of asylum seekers and refugees throughout Indonesia for September 2018.

90 Angela Jelita, op.cit.
} 
Juridically, national human rights instruments as referred to in Article 28D paragraph (2) of the 1945 Constitution and Article 38 of Law Number 39 of 1999 support the granting of rights. In addition, there is also no prohibition on override this right under Article 28J paragraph (2) of the 1945 Constitution, which states that the Law in the public interest of the State can limit a right. Until now, besides giving the right to work for refugees, it is very contrary to the principle of protection for refugees, also still unclear.

The Presidential Regulation 125 of 2016 on the Handling of Foreign Refugees separates the terminology of refugee and illegal immigrant. Therefore, immigration authority cannot provide immigration treatment as referred to in the Law Number 6 of 2011 on Immigration. Besides that, after the issuance of the Regulation, there are no rules that prohibited the right to work for refugees. ${ }^{91}$ This factor causes refugees to be unclear.

As such, immigration provisions do not apply to refugees who have obtained their status as refugees. For example, the Regulation of the Director General of Immigration Number IMI-1489.UM.08.05 of $2010^{92}$ prohibited refugees from working has been declared invalid. The Presidential Regulation Number 125 of 2016 revoked it. The Presidential Regulation Number 125 of 2016 actually regulates the prohibition and permissibility of refugees to work. ${ }^{93} \mathrm{~A}$ refugee will be subject to immigration actions based on the Law Number 6 of 2011 if the refugee status of the person is revoked so that his status changes which previously was a refugee being an illegal immigrant who is the authority of the Directorate General of Immigration. Compared to the implementation in other countries, it is considered effective enough to overcome the problems of refugees by empowering these refugees, such as in Malaysia and Thailand. Malaysia and Thailand are able to accommodate refugees of up to hundreds of thousands of refugees with minimal problems, even though the two countries have not ratified the 1951 and 1967 Protocols. Another example is in Chile, which has a quite interesting concept by providing accommodation before the refugees are slowly empowered in the community to reduce the accommodation.

Based on the description above, the solutions and policy concepts related to work rights that can be applied by refugees in Indonesia are by empowering refugees in certain sectors with special skills that have low competitiveness. In Malaysia and Thailand for example, employing refugees in oil palm and rubber fields because of the low labor competition in the sector where only a few people want to

91 Interview with Jaya Saputra as the Head of the Division of Detention and Deportation of the Directorate General of Immigration on December 17, 2018.

92 The Regulation of the Director General of Immigration Number IMI-1489.UM.08.05 of 2010 on the Handling of Illegal Immigrants.

93 Interview with Jaya Saputra as the Head of the Division of Detention and Deportation of the Directorate General of Immigration on December 17, 2018. 
carry out the profession in that country. ${ }^{94}$ This method is considered effective in minimizing competition with the local community so that it does not have a significant economic impact, considering that refugees can only access the employment because of skills that the local community do not have. For example, refugees in Indonesia have an advantage in the field of language, namely their native language, English, and Indonesian. If you have adapted it in Indonesia and are already fluent in using Indonesian, it will be a point that can be used, and maybe the government or related institutions, so that they can be empowered by getting paid for the results of these services. Refugees who work as translators can live their lives and can even go to college with fees from services for the profession. ${ }^{95}$

As another solution, we can use the concept of Chile by empowering refugees slowly and not directly allowing them to go into the community. Before being empowered, the refugees must be given training to use Indonesian first to facilitate refugees when they interact with the community later and these ability can be used by refugees to get jobs such as becoming language teachers or translators. ${ }^{96}$ However, we still need to study more deeply by considering the impacts of various aspects for the sake of the future to create integration between sovereignty and respect for human rights in dealing with the problems of refugees in Indonesia.

\section{E. Conclusions}

In general, the problems of applying alternative to detention in dealing with the problem of refugees in Indonesia, especially after the issuance of Presidential Regulation Number 125 of 2016 on the Handling of Refugees are (1) temporary shelter, which is the main solution for the implementation of Alternative To Detention; (2) a clash between sovereignty and respect for human rights; (3) the absence of adequate legal protection due to the absence of regulations on rights, obligations, and access that can be given to refugees living in the territory of Indonesia.

Regarding the problems, the Indonesian government needs to find new ways, options, or policies in addition to using a community house and shelter as an alternative of detention that can be implemented in Indonesian jurisdiction. To determine ways, options, or policies is by paying attention to the legal protection that can be given to refugees based on Article 3 of the Presidential Regulation Number 125 of 2016 and protection of human rights, which is recognized by Indonesia based on national human rights instruments.

This study recommends that improvements be made to alternative to detention regulations from the government in the form of creative policies to ensure the application of alternative to detention to deal with refugee problems in the Indo-

\footnotetext{
Ibid.

Interview with Ahmad Gym, an Afghan refugee who settled in the Indonesia on January 3, 2019.

See UNHCR, "Options Paper 2: options for government on open reception and alternatives to detention", https://www.unhcr.org/553f58719.pdf, accessed on April 2019.
} 
nesian territory. The improvement shall not violate refugee rights and against state sovereignty or public order. It requires regulations that specifically regulate rights, obligations, access, and restrictions given to refugees as long as they stay temporarily in Indonesian territory before being placed in third countries for the benefit of human rights.

\section{References}

\section{Books}

Boer Mauna, Hukum Internasional: Pengertian, Peranan dan Fungsi dalam Era Dinamika Global, PT Alumni, Bandung, 2013.

Jahawir Thontowi dan Pranoto Iskandar, Hukum Internasional Kontemporer, PT Refika Aditama, Bandung, 2016.

Majda El Muhtaj, Dimensi-Dimensi HAM: Menggurai Hak Ekonomi, Sosial, dan Budaya, Rajawali Pers, Jakarta, 2013.

McAuliffe, Marie, Khalid Koser (eds.), A Long Way to Go: Irregular Migration Patterns, Processes, Drivers, and Decision-making, Canberra: ANU Press, 2017.

Wagiman, Hukum Pengungsi Internasional, Sinar Grafika, Jakarta, 2012.

Yahya Sultoni, (et.al.), Alasan Indonesia Belum Meratifikasi Konvensi 1951 Tentang Pengungsi dan Perlindungan Hukum Bagi Pengungsi di Indonesia, Fakultas Hukum Universitas Brawijaya, Malang, 2014.

\section{Other Documents}

Adlya Nova, "Perlindungan Hak Asasi Manusia Terhadap Pengungsi Dan Pencari Suaka Di Rumah Detensi Imigrasi Indonesia Berdasarkan Perspektif Hukum Internasional (Konvensi 1951 dan Protokol 1967)", undergraduate thesis, Faculty of Law Universitas Sumatera Utara, 2017.

Anbar Jayadi, "merasa terasing pengungsi di Indonesia rentan bunuh diri", https://theconversation.com/merasa-terasing-pengungsi-di-indonesia-rentanbunuh-diri-95072, accessed on October 2018.

Angela Jelita, "Suicide, depression and poverty: Indonesia's refugees' bleak future now there's almost no chance of being resettled", https://www.scmp.com/lifestyle/article/2137993/suicide-depression-andpoverty-indonesias-refugees-bleak-future-now-theres, accessed on December 2018.

Cochane, Joe, "Refugees in Indonesia Hoped for Brief Stay. Many May Be Stuck for Life", https://www.nytimes.com/2018/01/26/world/asia/indonesia-refugeesunited-nations.html, accessed on April 2019.

Edwards, Alice, "From Routine to Exceptional: Introduction to UNHCR's Global Strategy-Beyond Detention 2014-2019: Supporting Governments to End the Detention of Asylum Seekers," Refugee Survey Quarterly, Vol. 35, 2016. 
Fitria, "Perlindungan Hukum Bagi Pengungsi di Negara Ketiga: Praktik Indonesia", Padjajaran Jurnal IImu Hukum, Vol. 2, 2015.

Intan Pelangi, "Perlindungan Terhadap Para Pencari Suaka Berdasarkan UndangUndang 39 tahun 1999", Padjadjaran Jurnal IImu Hukum, No. 4, 2017.

Malahayati, (et.al.), "Konsep Perlindungan Hukum dan Hak Asasi Manusia Terhadap Penata Laksana Rumah Tangga Indonesia”, Jurnal Nanggroe, Vol. 4, No. 1, 2015.

Missbach, Antje, "Accommodating Asylum Seekers and Refugees in Indonesia: From Immigration Detention to Containment in Alternatives to Detention", Refuge: Canada's Journal on Refugees/Refuge: revue canadienne sur les réfugiés, 2017.

Opeskin, Brian, and Daniel Ghezelbash, "Australian Refugee Policy and its Impacts on Pacific Island Countries", Asia and Pacific Studies, Vol. 36, 2016.

Rizki Akbar Hasan, "UNHCR Minta Pemerintah RI Upayakan Pemberdayaan Pengungsi di Indonesia". https://www.liputan6.com/global/read/3490924/unhcr-minta-pemerintah-riupayakan-pemberdayaan-pengungsi-di-indonesia, accessed on April 2019.

UNHCR, "Beyond Detention 2014-2019: Global Strategy", https://www.unhcr.org/53aa929f6.pdf, 2014.

-------, "Beyond Detention 2014-2019:National Action Plan- Indonesia", http://www.unhcr.org/53aa929f6.pdf, accessed on September 2018.

---------, "Guidelines on the Applicable Criteria and Standards relating to the Detention of Asylum-Seekers and Alternatives to Detention", https://www.refworld.org/docid/503489533b8.html, 2012.

--------, “Options Paper 2: options for government on open reception and alternatives to detention", https://www.unhcr.org/553f58719.pdf, accessed on April 2019.

--------, “Progress Report Mid-16: Beyond Detention 2014-2019", https://www.refworld.org/docid/57dff0a912.html, 2016.

---------, “Report: Indonesia", http://reporting.unhcr.org/node/10335, accessed on April 2019.

--------, "Resettlement", https://www.unhcr.org/resettlement.html, accessed on April 2019.

--------, "The 10 -Point Plan (Solution for refugees: Chapter 7)", https://www.unhcr.org/50a4c17f9.pdf, accessed on April 2019.

White House, "Executive Order 13769 of January 27, 2017: Protecting the Nation from Foreign Terrorist Entry into the United States," Federal Register 82, Vol. 20, 2017, https://www.govinfo.gov/content/pkg/FR-2017-02-01/pdf/201702281.pdf, accessed on April 2019. 
Yuliana Primawardani and Arief Rianto Kurniawan, "Penanganan Pengungsi dari Luar Negeri oleh Petugas Rumah Detensi Imigrasi di Provinsi Sulawesi Selatan", Jurnal IImiah Kebijakan Hukum, Vol. 12, 2018.

\section{Legal Documents}

1945 Constitution of the Republic of Indonesia [Undang-Undang Dasar Negara Republik Indonesia 1945].

Law Number 37 of 1999 on Foreign Relations [Undang-Undang Nomor 37 Tahun 1999 tentang Hubungan Luar Negeri].

Law Number 39 of 1999 on Human Rights [Undang-Undang Nomor 39 Tahun 1999 tentang Hak Asasi Manusia].

Law Number 24 of 2000 on International Treaties [Undang-Undang Nomor 24 Tahun 2000 Tentang Perjanjian Internasional].

Law Number 8 of 2011 on Immigration [Undang-Undang Nomor 6 Tahun 2011 tentang Keimigrasian].

Regulation of the President of the Republic of Indonesia Number 125 of 2016 on the Handling of Foreign Refugees [Peraturan Presiden Nomor 125 Tahun 2016 tentang Penanganan Pengungsi dari Luar Negeri].

Instruction of the Director General of Immigration Number IMI-GR.02.03-1910 on the Amendment to the Policy for Handling Asylum Seekers and Refugees by IOM on April 30, 2018 [Instruksi Direktur Jenderal Imigrasi Nomor: IMIGR.02.03-1910 perihal Perubahan Kebijakan Penanganan Pencari Suaka dan Pengungsi oleh IOM tanggal 30 April 2018].

Instruction of the Ministry of Law and Human Rights, the Directorate General of Immigration Number IMI-UM.01.01-2827 on the Return of the Function of the Immigration Detention House on July 30, 2018 [Instruksi Kementerian Hukum dan Hak Asasi Manusia Direktorat Jenderal Imigrasi Nomor: IMI-UM.01.012827 perihal Pengembalian Fungsi Rumah Detensi Imigrasi tanggal 30 Juli 2018].

Convention on the Status of Refugees, 1951.

Protocol on the Status of Refugees, 1967.

International Convention on Civil and Political Rights, 1969. 